\title{
Palatal tremor after lithium and carbamazepine use: a case report
}

\author{
Rajnarayan Mahasuar, Anju Kuruvilla* and KS Jacob
}

\begin{abstract}
Introduction: Palatal tremor, characterized by rhythmic contractions of the soft palate, can occur secondary to pathology in the dentato-rubro-olivary pathway, or in the absence of such structural lesions. Its pathogenesis is only partially understood. We describe a case of probable drug-induced palatal tremor.

Case presentation: A 27-year-old Indian man had taken carbamazepine and lithium for 7 years for the treatment of a manic episode. He presented with a one-year history of bilateral rhythmic oscillations of his soft palate and tremors of his tongue. There were no other abnormalities detected from his examination or after detailed investigation.
\end{abstract}

Conclusion: Palatal tremors may result from medication used in the treatment of psychiatric disorders.

\section{Introduction}

Palatal tremor (PT), previously referred to as palatal myoclonus, is characterized by rhythmic contractions of the soft palate. Symptomatic PT is diagnosed secondary to lesions in the dentato-rubro-olivary pathway. On the other hand, essential PT has no known structural lesions.

Bipolar affective disorder is a mental illness with an annual incidence of less than $1 \%$ and a lifetime prevalence of $0 \%$ to $7.8 \%$ [1]. It is characterized by recurrent periods of depression that alternate with periods of hypomania or mania. Mood stabilizers, such as lithium, sodium valproate and carbamazepine, are recommended in the treatment of acute mania. These are also used as prophylactic agents in the treatment of bipolar disorders [2]. We report the case of a patient with $\mathrm{PT}$ associated with the prolonged use of lithium and carbamazepine.

\section{Case presentation}

A 27-year-old Indian man presented with complaints of a clicking sound upon partially opening his mouth. He had experienced this symptom for the past year.

Relatives had observed that the sounds were absent when he was asleep. Our patient had had a single episode which was suggestive of mania with psychotic symptoms seven years prior to presentation. Since then he had been taking a combination of lithium and carbamazepine con-

* Correspondence: sanju@cmcvellore.ac.in

1 Department of Psychiatry, Christian Medical College, Vellore 632002, India Full list of author information is available at the end of the article tinuously as he felt there had been mild fluctuations in his mood when he had attempted to discontinue the drugs. There had been no changes in his drug dosage prior to the onset of his palatal problems. He had no history of using antipsychotic medication. He also had no other significant personal, medical or family history of neuropsychiatric illness. On his detailed psychiatric evaluation, no anxiety, mood or psychotic symptoms were found.

The results of our patient's physical examination revealed bilateral rhythmic oscillations of his soft palate associated with a clicking sound and tremors of the tongue,which were not synchronous with his palatal movements. The clicking sound was not audible when his mouth was closed or wide open. With distraction, his tongue tremors reduced in intensity but no obvious change in the clicking sound was noticed. As such, there was no obvious evidence that our patient's palatal movements were under voluntary control. He had no difficulty in speaking or swallowing. There were also no abnormalities in his eye movements.

An examination of his other systems did not reveal any abnormalities. The results of his routine blood tests, as well as liver, kidney and thyroid function tests, were all normal. The results of his brain magnetic resonance imaging (MRI), electroencephalography (EEG), electromyography (EMG), and a laboratory work-up for Wilson's disease were also normal. His serum carbamazepine and lithium levels were $5.47 \mathrm{mcg} / \mathrm{mL}$ (target blood level 4 
$\mathrm{mcg} / \mathrm{mL}$ to $12 \mathrm{mcg} / \mathrm{mL}$ ) and $0.57 \mathrm{mmol} / \mathrm{L}$ (target blood level $0.8 \mathrm{mmol} / \mathrm{L}$ to $1.2 \mathrm{mmol} / \mathrm{L}$ ), respectively.

We considered a diagnosis of tardive PT, so his lithium dosage was tapered off and then stopped. We continued his carbamazepine dosage and started him on a therapy of clonazepam at $0.25 \mathrm{mg}$ twice daily. Subsequently, his visible tongue tremors were reduced in a week and by the end of one month he subjectively reported an improvement of about $60 \%$ in his tremors and clicking sound. Over the next three months of follow-up, our patient reported a periodic fluctuation in the intensity of his symptoms but with no further sustained improvement.

\section{Discussion}

Palatal tremor is characterized by rhythmic movements of the soft palate. These movements are repetitive audible clicks [3] which are thought to be related to the opening and closing of the eustachian tube [4]. In the past, several terms have been used to describe this condition. At present, however, it is thought to be best classified phenomenologically as a tremor [5].

Symptomatic PT is associated with hypertrophic olivary degeneration that is visible on an MRI scan. It also has multiple causes, the most common being vascular. This particular PT persists during sleep and is associated with ocular and cerebellar signs.

Meanwhile, essential PT is thought to be heterogeneous and modified by sleep, neck position or mouth opening, and rarely involves the eyes [6]. It is proposed that some 'essential' tremors of the palate may in fact be centrally generated $[6,7]$ while others may be peripheral or mechanical in origin, psychogenic, voluntary, or multifactorial in nature [5]. A psychogenic origin is suspected when the movement is reduced by distraction, when other psychopathology is present, when the symptoms respond spontaneously to a placebo, or improvement occurs faster than expected by therapy [8]. Epileptic palatal myoclonus is uncommon and is associated with cortical dysfunction on EEG [9].

In our patient, in the absence of other causes, the possibility of a tardive, drug-induced PT was considered. Lithium, in therapeutic and toxic levels, is known to produce a variety of movement disorders. A low-amplitude and fast postural tremor of the hands, which can worsen during activities requiring fine motor control, is commonly observed [10]. Myoclonus of the limbs [11] and tardive syndromes [12] have also been reported. Although carbamazepine can produce tremors, especially when combined with lithium and neuroleptics, and can worsen essential tremors [13], it is also recommended as a treatment of PT [14] and myoclonus [15]. While drug-induced PT has been observed with the use of ciprofloxacin [16], to the best of our knowledge this is the first report of pal- atal and lingual tremors associated with the use of lithium and carbamazepine.

Since the withdrawal of lithium and the introduction of clonazepam occurred simultaneously in our case, we cannot assume that the reduction in symptoms was solely due to the removal of lithium. The persistence of the symptoms despite the complete withdrawal of lithium may suggest that carbamazepine also has a role in the manifestation of his symptoms.

The pharmacological treatment for PT includes a variety of agents such as anticonvulsants, benzodiazepines, anticholinergic agents, calcium channel blockers (flunarizine), 5-hydroxytryptamine (5HT) and 5HT agonists (sumatriptan), nootropics (piracetam), placebos and botulinum toxin [17]. Tonsillectomy and other local therapies [7], relaxation techniques, voluntary mechanisms [17] such as the Valsalva maneuver, and dental devices [18] have also been attempted. However, the response of patients to these interventions is varied.

\section{Conclusion}

Palatal tremor is an uncommon movement disorder that can occur following the prolonged use of psychotropic medication. Clinicians prescribing these drugs must take measures to reduce the risk of such disorders by carefully monitoring for the development of associated symptoms in their patients.

\section{Consent}

Written informed consent to publish could not be obtained despite reasonable attempts. All efforts have been made to protect the identity of the patient and there is no reason to believe that he would object to its publication.

\section{Competing interests}

The authors declare that they have no competing interests.

\section{Authors' contributions}

$\mathrm{RM}$ and KSJ took care of our patient and contributed to the conception of the case report. AK undertook the literature review and drafted the manuscript. All authors read and approved the final manuscript.

\section{Author Details}

Department of Psychiatry, Christian Medical College, Vellore 632002, India

Received: 21 October 2009 Accepted: 11 June 2010

Published: 11 June 2010

\section{References}

1. Sadock BJ, Sadock VA: Mood disorders. In Kaplan and Sadock's Synopsis of Psychiatry: Behavioral Sciences/Clinical Psychiatry 9th edition. Edited by: Sadock BJ, Sadock VA. Philadelphia: Lippincott Williams and Wilkins; 2003:529.

2. Martinez M, Marangell LB, Martinez JM: Psychopharmacology. In The American Psychiatric Publishing Textbook of Psychiatry 5th edition. Edited by: Hales RE, Yudofsky SC, Gabbard GO. Washington DC: American Psychiatric Publishing Inc; 2008:1106. 
3. Adams RD, Victor M, Ropper AH: Tremor, myoclonus, focal dystonias, and tics. In Principles of Neurology 6th edition. Edited by: Adams RD, Victor M, Ropper AH. New York: McGraw- Hill; 1997:101.

4. Samuel M, Torun N, Tuite PJ, Sharpe JA, Lang AE: Progressive ataxia and palatal tremor (PAPT): clinical and MRI assessment with review of palatal tremors. Brain 2004, 127:1252-1268.

5. Zadicoff C, Lang AE, Klein C: The 'essentials' of essential palatal tremor: a reappraisal of the nosology. Brain 2006, 129:832-840.

6. Pearce JM: Palatal myoclonus (syn palatal tremor). Eur Neurol 2008, 60:312-315

7. Haller S, Winkler DT, Gobbi C, Lyrer P, Wetzel SG, Steck AJ: Prominent activation of the putamen during essential palatal tremor: a functional MR imaging case study. Am J Neuroradiol 2006, 27:1272-1274.

8. Marjama J, Troster Al, Koller WC: Psychogenic movement disorders. Neurol Clin 1995, 13:283-297.

9. Noachtar S, Ebner A, Witte OW, Seitz RJ: Palatal tremor of cortical origin presenting as epilepsia partialis continua. Epilepsia 2005, 36:207-209.

10. Sadock BJ, Sadock VA: Biological therapies. In Concise Textbook of Clinical Psychiatry 3rd edition. Edited by: Sadock BJ, Sadock VA. Philadelphia: Lippincott Williams and Wilkins; 2008:514-519.

11. Caviness JN, Evidente VG: Cortical myoclonus during lithium exposure. Arch Neurol 2003, 3:401-404.

12. Muthane UB, Prasad BN, Vasanth A, Satishchandra P: Tardive Parkinsonism, orofacial dyskinesia and akathisia following brief exposure to lithium carbonate. J Neurol Sci 2000, 1:78-79.

13. Smaga S: Tremor. Am Fam Physician 2003, 68:1545-1553.

14. Rahko T, Häkkinen V: Carbamazepine in the treatment of objective myoclonus tinnitus. J Laryngol Otol 1979, 93:123-127.

15. Yigit A, Sarikaya S: Myoclonus relieved by carbamazepine in subacute sclerosing panencephalitis.Epileptic Disord. Epileptic Disord 2006, 8:77-80.

16. Cheung Y, Wong WW, Tang K, Chan JH, Li PC: Ciprofloxacin-induced palatal tremor. Mov Disord 2007, 22:1038-1043.

17. Campistol-Plana J, Majumdar A, Fernández-Alvarez E: Palatal tremor in childhood: clinical and therapeutic considerations. Dev Med Child Neurol 2006, 48:982-984.

18. Mondria T, de Gier HH, Boon AJ: New device to control combined lingual and palatal myoclonus. Mov Disord 2007, 22:573-576.

doi: 10.1186/1752-1947-4-176

Cite this article as: Mahasuar et al., Palatal tremor after lithium and carbamazepine use: a case report Journal of Medical Case Reports 2010, 4:176

Submit your next manuscript to BioMed Centra and take full advantage of:

- Convenient online submission

- Thorough peer review

- No space constraints or color figure charges

- Immediate publication on acceptance

- Inclusion in PubMed, CAS, Scopus and Google Scholar

- Research which is freely available for redistribution

Submit your manuscript at www.biomedcentral.com/submit
C Biomed Central 